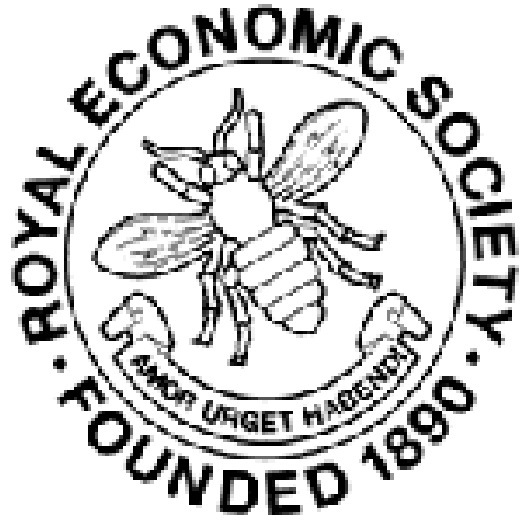

Labour Organisation in the Cutlery Trade of Solingen

Author(s): G. I. H. Lloyd

Source: The Economic Journal, Vol. 18, No. 71 (Sep., 1908), pp. 373-391

Published by: Wiley on behalf of the Royal Economic Society

Stable URL: http://www.jstor.org/stable/2221552

Accessed: 27-06-2016 10:40 UTC

Your use of the JSTOR archive indicates your acceptance of the Terms \& Conditions of Use, available at

http://about.jstor.org/terms

JSTOR is a not-for-profit service that helps scholars, researchers, and students discover, use, and build upon a wide range of content in a trusted digital archive. We use information technology and tools to increase productivity and facilitate new forms of scholarship. For more information about JSTOR, please contact support@jstor.org.

Royal Economic Society, Wiley are collaborating with JSTOR to digitize, preserve and extend access to The Economic Journal 


\section{LABOUR ORGANISATION IN THE CUTLERY TRADE OF SOLINGEN.}

THE German cutlery industry, which is almost entirely localised in the town and neighbourhod of Solingen, presents many of the interesting features which are familiar to those acquainted with the light trades of Sheffield, and offers in addition a remarkable example of successful labour organisation, which has no equivalent in the English cutlery centre. Solingen differs from Sheffield in being a small town of 50,000 inhabitants, whereas Sheffield contains nine times that number. Indeed, the population of the whole area of the industry, including Solingen and the surrounding country, together with the adjacent towns of Gräfrath, Höhscheid, Wald, and Ohligs, does not number onethird of the inhabitants of Sheffield. Throughout this area the staple industry is the manufacture of cutlery-the manufacture of tools, saws, and files, which are also Sheffield trades, being carried on in the neighbouring town of Remscheid, under totally different conditions, while to find the equivalent of the heavy steel trade of Sheffield it would be necessary to include the town of Essen.

Sheffield and Solingen have for many generations been keen competitors in the world's markets. They are curiously similar in situation. Both in the past have profited by the abundance of waterpower on the small streams in their respective neighbourhoods, and the easy access to suitable stone for grinding, while the mountains of Westerwald formerly supplied Solingen with an abundant supply of natural steel of a fair quality, obtained directly by smelting with chareoal. To-day steam in Sheffield, and electric power in Solingen, are taking the place of the water-wheels, the grindstones are no longer purely local in origin, and both towns alike make large use of the finest Swedish iron, which is converted into steel in Sheffield. Again, in both places the large proportion of the operatives who are "outworkers," have retained down to 
the present day some of the independence of the mediæval craftsmen. Although they no longer own the actual materials of their work, they still own all the necessary tools and equipment, and work at a time and place largely within their own discretion. Among the outworkers of Solingen, the threefold division into " master" workman, journeyman (or "datal man," as he is called in Sheffield), and legally bound apprentice, is still sharply defined.

In Solingen the craft of the sword-maker has been carried on from the earliest times, and already in the fifteenth century they were incorporated in three Companies of the Sword-smiths, the Temperers and Grinders, and the Finishers, which were mutually exclusive as to membership. Originally all blades were forged by hand, but mechanical hammers driven by water-power came into use in the sixteenth century, and a vain attempt in the year 1687 to prohibit the use of blades made in this manner only served to mark the predominance of the new method. Side by side with the technical transformation an economic revolution took place; there grew up a body of capitalistic merchants or factors, and the workers became wage-earners, working on material supplied by the merchants. In 1571 the knife-makers in their turn attained to the privilege of an independent incorporation-six years later than the date of the earliest known Ordinances of the Sheffield Cutlers, though the members of the Sword-makers' Companes retained the right to exercise this humbler craft until the middle of the century following. In 1596 Ordinances were passed requiring each master to be fully qualified as forger, cutler, and finisher; he was forbidden to employ more than one journeyman and one apprentice at a time; the use of blades made under mechanical hammers was forbidden; he was required to strike his own mark on all his work. The Ordinances of 1687 were intended to re-establish the position of the worker as an independent craftsman, and to check the transition to the status of mere wage-earner, but by the middle of the eighteenth century the change was complete, and from that time onward the economic conflict has centred in the problem of maintaining a fixed scale of wages for the various branches of the industry. The grinders had already become wage-earners by 1607 , when they obtained their first official scale, and this was extended to all branches in 1673. The last general scale under the Guild system was ratified in 1789 . It gave 211 specific prices for the detailed work of forging and grinding knives, 200 prices for the details of cutler's work, 10 prices for gold and silver decoration, 64 prices for fork grinding, and a complicated list of prices for 
forging and grinding pocket knives, arranged in seven classes. The ancient rule that no master should employ more than one journeyman and one apprentice was reaffirmed. In 1794 the Scissor Makers-a body of about 200 master workmen and their assistants, hitherto outside the Cutlers' organisation-obtained a grant of incorporation, being the last section to be admitted to such privileges. In 1809, however, the whole Guild organisation was swept away, and a period of industrial anarchy engulfed the workers, who numbered more than 4,700, and rendered them powerless to withstand the devastating spread of the "truck" system, which was carried on by the merchants. This system of payment reached its full development in the period 1820-1840, and contributed greatly to the degradation of the ancient industry, and caused it to acquire an evil reputation, since the standard of workmanship sank to a low level under these conditions. In 1840 the establishment of an Industrial Court with a Board of Conciliation in Solingen provided some means of bringing the employers and their workers into harmonious relations; but the modern organisation does not really begin until after the concession of the right of combination in 1869. Since that time the workers have been able to re-establish their position as independent outworkers, and to offer a stout resistance to the inevitable trend towards factory organisation.

In Sheffield, at the present time, the large factory with many departments embracing all the various processes tends more and more to become the dominant type, and there is a steady though gradual decline of the system of outwork, which is now mainly restricted to those who work for " little masters," though there are but few firms which give out no work at all. There are two classes of "little masters" ; the first occupy a small office and warehouse, and have little or no work done on the premises, but utilise the labour of outworkers, generally those who are neediest and the poorest workmen. They buy the parts of the article stamped out by machinery, and, having had them worked up, travel round to country towns and watering-places selling at prices at which they can defy the larger establishments who have heavy fixed charges and higher wage rates to meet. The other class are working grinders, or cutlers who employ a team of two to six men on time wages to work with them. Such a man rents a whole room in a tenement factory - a cutler's shop or grinding " hull " as the case may be-and takes work wherever he can find it, either from the warehouse of one or more of the larger factories, or from little masters who do a factoring trade. Other outworkers are 
single-handed, or employ a man and possibly a boy to assist them ; such was commonly the rule of the trade when the Unions were stronger. The outlook in the trade is not sufficiently attractive to cause a superabundance of boys. In the hand-forging branches the personnel is practically stationary, and the trade is rapidly being transferred to the mechanical hammers.

In Solingen, as in Sheffield, the transition from domestic to factory organisation is steadily proceeding; indeed, in the manufacture of arms it is already accomplished, with the sole exception of the hardening process. In all branches the substitution of mechanical for hand hammers has transferred the forging process to the factories, in this respect presenting a contrast to Sheffield, where much of the finest cutlery is still hand-forged. The machine-grinding of razors has also found a foothold in Solingen, and electric ovens for tempering have reached an experimental stage. On the other hand, the operations subsequent to forging, namely the tempering, grinding and glazing, filing, hafting and finishing processes still to a large extent take the form of outwork, and are likely to remain so. A significant check has been given to the concentration in factories by the very rapid diffusion of electrical energy which has taken place among the outworkers; this enables them to have at their command, in whatever quantity may be desired, the assistance of motive power for drills, lathes, grindstones and polishing wheels, and at the same time provides them with electric lighting-an important advantage where fine work is undertaken. To the grinders it has proved especially beneficial, since it has rendered possible the multiplication of private grinding shops attached to dwelling houses in the suburbs, and has thereby improved the position of many who would otherwise have to work either in the water-driven grinding wheels which are found on all the streams in the district, or in the steam-driven factories in the town. Thus, by means of these private installations, a positive extension of outwork has recently taken place, and fresh shops are being provided at the rate of 200 per annum, half of which are grinding wheels. It may, indeed, be said that all manufacturers give out more work than they carry out in their own factories, and the largest firm in Solingen, who employ 2,400 workers, only find work for some 800 on the premises.

The outworking grinder either occupies his own shop, sometimes singly, sometimes in partnership with one or more fellowworkers, or rents a "Stellung" (or "trow" as it is called in Sheffield) from the proprietor of a tenement factory, paying a 
weekly rent of from $1 s$. to $6 s$. per week, the larger sum being the most usual, but the former price still to be found in some of the more dilapidated water-driven wheels. For this rent he obtains shop room and power, but must supply his own grindstone (a new stone costs $£ 7$ to $£ 8$ ), glazers, and other tools. ${ }^{1}$ If he employs another man or an apprentice to work with him he must pay double rent. The wages for which he works are thus subject to important deductions, which render the calculation of nett wages and nett labour cost of production a matter of some complexity. The local income-tax regulations allow a deduction from a grinder's gross earnings, on account of expenditure on tools and rent, varying from 20 per cent. in the case of razor grinders to $33 \frac{1}{3}$ per cent. in the case of sword grinders. Even these figures do not, in some cases, represent the full extent of the outlay involved.

At the opening of the nineteenth century there were in Solingen and the neighbourhood 4,700 cutlery workers, distributed as follows :-

\begin{tabular}{|c|c|c|c|c|}
\hline & $\begin{array}{c}\text { "Privileged" } \\
\text { master } \\
\text { workmen. }\end{array}$ & $\begin{array}{l}\text { Their } \\
\text { assistants. }\end{array}$ & $\begin{array}{c}\text { "Unprivileged" } \\
\text { workers. }\end{array}$ & Total. \\
\hline Sword makers ............. & 580 & 480 & 570 & 1,630 \\
\hline Knife makers ............. & 400 & 600 & 700 & 1,700 \\
\hline Scissors makers .......... & 200 & 200 & 100 & 500 \\
\hline Grinders $\quad \ldots \ldots \ldots \ldots \ldots \ldots$ & 500 & 400 & - & 900 \\
\hline & 1,680 & 1,680 & 1,370 & 4,730 \\
\hline
\end{tabular}

It is noticeable that a considerable proportion of the total number of workers at that time consisted of " wild," or unprivileged men, who were included in the Guild. There were then 93 grinding wheels in the Solingen district. Work was irregular, being checked by frost in winter and by drought in summer, as well as by bad trade; thus the grinder commonly spent part of his time in cultivating a plot of land. Steam wheels were first introduced about 1850. In 1832 there were 89 wheels; in 1860 there were 105 ; in 1895 the number had risen to 189 , of which 63 were driven by water and 107 by steam. There are now some 700 grinding wheels, less than 30 being driven by water power, the greater number being small establishments with electric installations.

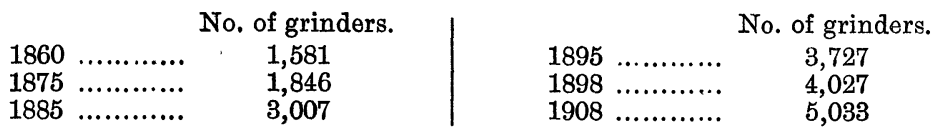

1 Similarly, a Sheffield table-blade grinder renting two "trows" has to provide for a weekly outlay of about $15 s$. for rent and $6 s$. for materials. 
Two-thirds of the grinders are now independent master workmen. The totaI number of cutlery workers is as follows :-

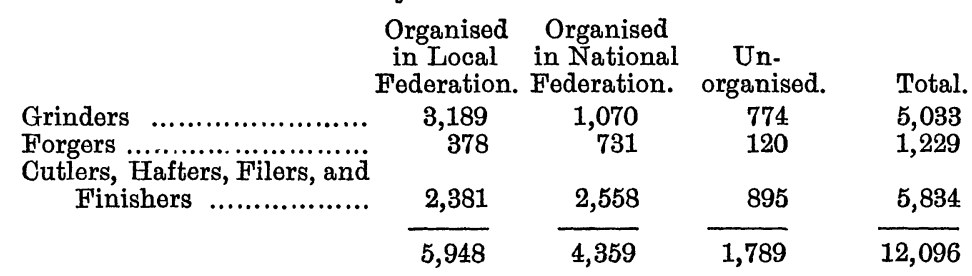

These figures are obtained from trade union sources, and may be taken to include all regular workers in the trade, though a strict census enumeration would probably increase the totals. The 12,000 thus employed are composed-in round numbersof the following groups:-

\begin{tabular}{|c|c|}
\hline & \\
\hline Employed in & Number. \\
\hline 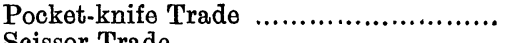 & 3,300 \\
\hline 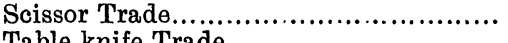 & 3,200 \\
\hline Table-knife Trade................................. & 2,000 \\
\hline Razor Trade & 2,000 \\
\hline 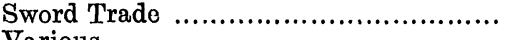 & 500 \\
\hline Various & 1,000 \\
\hline & 000 \\
\hline
\end{tabular}

The four chief departments of the cutlery industry are the forging, the grinding, the putting together or cutler's work proper, and the final finishing, the first and the last being almost entirely carried out in the factories. In the forging process much machinery is employed. For razors and scissors die forging under a drop hammer is usual ; for table and pocket blades trip and tilt hammers are used, and in the case of the table blades more elaborate machines with two or four hammers operating against one another simultaneously. In all cases the superfluous metal is then sheared off, and the exact contour given to the article in a cold fly-press. In the case of mechanically forged goods, owing to the regularity of form attained, there is probably some saving of labour in the subsequent processes of grinding or filing, particularly in the case of hollow forged razors. The grinding proper is carried out on large sandstone wheels, often seven to nine feet in diameter, moistened by a slight stream of water from a pipe. The top of the stone revolves towards the grinder as he sits facing it, holding his work against the face of the stone, with the help of hands and knees, some eighteen inches from the ground. This process finished, the same man takes his work to another room for the "glazing" or finer grinding; this is done on revolving disks of wood, about 18 inches in diameter, the leather-coated periphery of which is dressed with emery powder of varying 
degrees of fineness. Goods of the best quality are given their final polish by means of rouge powder, on a wheel covered with soft leather, or by using a revolving brush or "dolly" and Vienna chalk. Work which cannot be adjusted to a revolving stone or wheel, such as scissor handles, must be filed. The occupation of the "cutler" proper is furnished by the process of putting together, as a pocket knife is built up out of numerous parts. The cutler's work is a succession of skilful manual adjustments, each knife being a unique agglomeration of parts which are not interchangeable with another knife out of the same batch. It is thus intelligible that the cutler, although his work is not particularly arduous or exacting, should enjoy a high reputation as a handy man for any manual job. The last process is that of the "finisher" in the factory, who gives the final external polish and leaves the article ready to hand to the customer.

Especially in the grinding and putting together of cutlery goods the system of outwork is still prevalent. The grinder needs only simple motive power, and the cutler, until recently, was accustomed to do without power altogether, to make all his borings, \&c., by hand, and to use a simple foot lathe to rotate his glazer.

In such circumstances the attempt to concentrate the work in factories brings with it few economies, but it facilitates labour organisation. Outworkers are difficult to organise even for so fundamental an object as the defence of a common piece-work price-list. When large numbers of them live beyond the limits of the town, and may even work in their own homes, they acquire little of the esprit de corps of a factory, and the price-lists are exceedingly difficult to preserve from the insidious attacks of discounts conceded by needy workmen here and there when work is scarce. The chief reason why the grinders both in Sheffield and Solingen have been better organised than the cutlers is that they are more congregated at their work. In Sheffield, indeed, owing to ineffective organisation, few if any of the printed price-lists which are still found in the cutlery trades are literally adhered to at the present time. In Solingen the case is quite otherwise.

Until recently the workers of Solingen were united in numerous sectional societies, each embracing those occupied in a single process in the manufacture of one of the staple articles. The formation of powerful sectional unions practically compelled the employers to unite in self-defence in their turn. Thus the basis of the present organisation is found in the existence of some thirty to forty sectional labour unions confronting a number of employers' associations. 
The most prominent of these employers' associations are those of the Sword Cutlery Manufacturers, the Pen and Pocket Knife Manufacturers, the Table Knife Manufacturers, the Razor Manufacturers, and two Associations of Forge Proprietors, one of which is confined to Pen and Pocket Blade Forge Proprietors. Naturally many of the employers belong to two or more of these societies, according to the scope of their businesses. The leading labour unions, with which these have to deal, are the Scissor Grinders' Union, with 1,250 members, the Table Blade Grinders, with about 900 members, the Razor Grinders with 700 members, the Pen and Pocket Knife Cutlers and Finishers, each with 650-700 members, the Table Blade, Scissor and Fork Forgers with 560 members, the Pen and Pocket Blade Forgers with 200, the three unions of Table, Butcher, Bread and Vegetable Knife Cutters, together including 480 members. It is worth while to glance at the history of the principal unions.

Scissor Grinders' Union.--After the concession of the right of combination by the law of 1869 , the grinders quickly seized the opportunity presented by a series of prosperous years, and built up a strong organisation. The Scissor Grinders' Union was established in 1872, and ever since that time has remained one of the most powerful societies. The policy of enforcing their demands on individual firms one at a time soon brought home to the employers the need for defensive alliances, and already in 1874 the Associated Scissor Manufacturers were able to make a firm stand for five months, during which period they gave out no work. In February, 1875, the injurious dispute came to an end, and an agreement was ratified which provided for the establishment of a joint Conciliation Board and a guaranteed piece-work price-list. Both sides were pledged to enforce the list on those masters or workmen who stood outside their respective organisations, and no alteration of the list could be entertained without three months' notice. Agreements of this character have been in force for thirty years, and recently their operation has been extended to most branches of the staple trade. The price-list for scissor grinding was modified in 1878, after which it was maintained unaltered until 1890 , in spite of severe trade depressions and the competition of "wild", or unorganised workers at lower prices. Some evasion occurred which was made possible by the connivance of individual grinders, as, for instance, by giving a "full polish" when only " threequarter polish" was entered and paid for, but when such practices were discovered the employer was compelled to refund the deficiency to the union. On the whole the agreement was successful in 
securing steadiness of wages and in maintaining the quality of work. An increased list was conceded in 1890, which survived an obstinate attempt to break through the agreement made by one of the most important firms in the district during the years 18981900. This dispute ended in a victory for the grinders and the recognition of an even more favourable price-list. In the following year the Manufacturers' Association attempted to effect a reduction, and the Conciliation Board in this case failed to attain a pacific arrangement, as did also a special Board appointed jointly by the Central Committee of the workers and the Federation of Manufacturers' Associations. The consequent strike and lock-out resulted, however, in the re-establishment of the scale, and in an undertaking to maintain it unaltered for three years. The present list dates from October, 1907. It is an elaborate pamphlet of 45 pages, one half of which is occupied by thousands of detailed prices applying to the immense variety of goods handled according to their kind, size and quality, the other half giving 125 drawings of the principal types of scissors dealt with and an index. The prices laid down are minimum prices, and are, as a matter of fact, exceeded by some of the best firms; they must be maintained under penalties by both the employers and the men. Repeated infringement involves the exclusion of the offending member from the society to which he belongs. The grinders may work for no master who does not pay the scale, and the employers are bound to refuse employment to any grinder who is convicted of taking less than the minimum. The Conciliation Board adjusts all questions which arise between the two organisations. Three months' notice of any proposed change of prices must be given, and alterations which are ratified by the Board can only come into force after another interval of three months, except by special agreement. The Board consists of seven employers and seven grinders appointed by their respective organisations; the chairman is an employer. The number of scissor grinders employed has trebled in thirty years.

Table Blade Grinders' Union.-As early as 1872 the table blade grinders carried out a successful agitation for a 25 per cent. increase of prices, in spite of the masters' refusal to supply work during a four months' dispute. Having little to fear from foreign competition they were able to dictate their own terms, and seem to have been masters of the situation during the period 1873-5, when the "king " of the grinders issued his mandates in the newspapers from day to day, and summoned employer and grinder alike to appear before him and justify wages given or received. The 
employers, however, in 1875 , followed the example of the scissor manufacturers, and formed an association. Two years later one of the chief firms attempted to introduce a new subdivision of work in the grinding and polishing, and to pay nett wages to their workers, the firm supplying all necessary tools and appliances. After a four months' dispute the association came to terms with the men, whereupon the firm referred to left the association and the union broke down. It was not until 1887 that the table knife manufacturers came to a mutual understanding with the Grinders' Union, and concluded the establishment of a price-list and a Conciliation Board. This Board was often called upon to investigate complaints against employers for abandoning the scale, and in many cases enforced the payment of an indemnity. In 1888 another important dispute occurred with reference to the system of work adopted by the above-mentioned firm. This firm supplied its grinders with all those tools and materials which the independent outworker found for himself, thus destroying all uniformity in the price paid for the work as compared with other firms, and in the eyes of the latter gaining for themselves an unfair advantage. In 1902 the Union demanded from the Manufacturers' Association an advance of prices; the association replied that the competition of such firms as the above was hitting their members hard, and that a reduction of wages instead of an increase would be required if it continued. They also reminded the grinders that they were not carrying out their agreement to work for no firm who evaded the price-list, and threatened to withdraw from their obligation not to employ grinders who worked below the list, so that they might be free, if they wished, to obtain goods from the illegal firms. In 1903 the manufacturers expressed their willingness to adopt a new price-list, including rates for work on the new system, on the grinders undertaking to see that the illegal firms promised their adhesion also. The firm with whom the trouble originated adopted a special scale of payment for subdivided work drawn up by a Commission, ${ }^{1}$ and undertook to observe the new price-list. After a sharp conflict the new list with increased rates was ratified, and all the old obligations were fully restored.

Pocket Knife Cutlers' Union.-In this branch home work abounds, and there is a natural tendency to call in the assistance of women and children; moreover, since the workers are widely

1 This firm pays nett wages, at a discount of $33 \frac{1}{3}$ per cent. from the price-list. Together with two or three other firms, where a system of subdivided labour is in force, they are strictly boycotted by the trade unions. 
scattered, and much of the work requires but little strength or skill, organisation is difficult, and standard rates are easily broken through under pressure of poverty. The Union was established in 1889 , but the prolonged negotiations for a common price-list were fruitless, and a five weeks' strike finally took place in January, 1895. Inquiries made at that time showed that there were 804 master workmen employed, assisted by 223 journeymen and 358 apprentices. Of this number 662 masters and 27 journeymen belonged to the Union; subdivision of employments and women's labour were common, and thirteen hours was the usual length of the working day. A Conciliation Board was established at the conclusion of the strike, which worked out definitions of standard qualities for the trade, but no agreement about prices could be attained, and the following year the dispute broke out afresh. This time the strike lasted seven weeks, and was assisted by contributions received from the cutlery unions in Sheffield. Finally a settlement was reached on the ground of mutual recognition of a price-list and the re-establishment of the Conciliation Board. A fresh list was adopted in 1900, which was enforced upon the manufacturers who were outside the Association. In 1904 there arose a difficulty with an important firm with regard to the calculation of deductions to be made from the list for work given out in a more advanced state than usual, certain preparatory work being performed in the factory. In spite of the comparative weakness of the organisation an agreement was reached after a short strike.

Pen and Pocket Knife Finishers' Union.-The finishers, to the number of 600 , stood firm through a ten weeks' strike before they succeeded in securing a recognised list. This struggle cost them $£ 5,000$, and similar sums were lost both by other branches of workers and by the employers. New lists were subsequently obtained in 1900 and in 1907.

Pocket Blade Grinders' Union.-This organisation was founded in 1872, and the Pocket Knife Manufacturers' Association in 1880. There was a strike in 1882, and a prolonged dispute in 1890, which was concluded on the recognition of a price-list and a Conciliation Board. Fresh agreements were ratified in 1907.

Forge Workers' Union.-In the machine forging, which has developed rapidly during the last twenty-five years, a price-list was first established in 1900, after an obstinate strike which caused the employers to unite in the Forge Proprietors' Association, and join in a common Conciliation Board. In this struggle the workers were supported by the German Metal-workers' Federation. The agreement in this case covers not only the establishment of 
an agreed price-list and a Conciliation Board, but also deals with hours of work, Sunday work, employment of youths, and other matters.

Both the employers' associations and the labour unions are respectively consolidated in wider federations. Thus many of the employers' federations belong to the "Verband der Fabrikantenvereine," which was founded in 1890, and re-established in 1900 , and which admits to membership not only employers' associations but also individual manufacturers who have no opportunity of joining any existing organisation. This federation forms a second line of defence against the trade unions, and a further means of negotiation in cases where the sectional Conciliation Board has failed to settle a dispute. Its membership includes the chief associations, namely, the Manufacturers of Scissors, Table Knives, Pocket Knives, Forks, and Razors. Side by side with this federation are two others, the "Verein zur Wahrung der wirtschaftlichen Interessen der Solingen Industrie" and the "Verband von Arbeitgebern im Kreise Solingen," both established in 1903. The former is composed of individual manufacturers who own their own works, those who only employ outworkers being specifically excluded. It is not confined to members of the cutlery trade. Voting is regulated by the total amount paid in wages and salaries during the previous year. The sum of $£ 1,500$ so paid gives a right to one vote, two are given for $£ 3,000$, three for $£ 5,000$, and an additional vote for each further $£ 2,500$ up to a possible maximum of twenty-one votes. The membership is not large numerically, yet it represents probably more than half the wages paid in Solingen, and the Association gains in solidarity what it loses in comprehensiveness. If one of the members is boycotted by a trade union no other member may employ the defaulting workers. On the other hand, a lock-out must be ratified by three-fourths of the votes at a special meeting. The other association, the "Federation of Employers in the Solingen District," tries to embrace all employers, whether as sectionally organised or as individual members. Voting power here also is proportioned to wages and salaries. The object is to form an organisation which may counterbalance the practically universal organisation of the men. The Federation is one of the numerous similar organisations which are united in the "Verein deutscher Arbeitgeber Verbände." It has a large membership, including the Associations of Foundry Proprietors, Sword-cutlery Manufacturers and Pocket-blade Forge Proprietors, and has on more than one occasion successfully intervened in disputes. 
The Labour Unions are united on their side in two wider federations, as well as by a Central Committee of delegates, or Trades Council, with somewhat extensive functions. The purely local federation of cutlery workers known as the "Industriearbeiter Verband," which includes more than two-thirds of the organised workers of the staple trade, is of recent origin. It is a manifestation of the spirit of sturdy independence and jealousy of external domination which actuates the workers of Solingen, and is a friendly opponent of the local branch of the national Federation of Metal Workers ("Deutscher. Metalarbeiter Verband"). The latter is not confined to cutlery workers, but includes metal workers in miscellaneous trades, the latter constituting half the membership of the branch. The rivalry between these two bodies has provided a keen stimulus towards effective organisation, and has materially contributed to the success of the labour movement in Solingen.

The "Central Committee of the Solingen Trade Societies" was founded in 1899, and is composed of delegates from the sectional Unions affiliated to it at the rate of one delegate for the first 100 members, and an additional delegate for each additional 300 members. The delegates appoint an executive committee of seven members and three supervisors. All the affiliated societies are bound to carry out the decisions of the Committee. The contributions are at the rate of $10 \mathrm{pfg}$. per month per member of the affiliated societies. The Committee gives no monetary assistance in the case of strikes or boycotts, except in extraordinary circumstances, but it affords legal defence in actions arising out of the activities of its members on its behalf. The Committee maintains a Labour Inquiry Bureau, which gives advice with regard to all matters relating to insurance, conditions of work, legal difficulties, taxes, military service, and the like; the Committee also pays special attention to the enforcement of the beneficial provisions of the Labour Laws, and supervises the elections to the Industrial Court.

The powerful and energetic organisation known as the German Metal Workers' Federation, itself a member of an international federation, has for years carried on a keen agitation in Solingen with the object of affiliating the local Unions. It has been joined by the old trade society of the Forge Workers, and by the Foundry Workers-both of these groups being factory workers-and by the bulk of the cutlers, grinders, and finishers of pen- and pocketknives, as well as by a large number of individual members belonging to other groups.

No. 71.- VoL. XVIII. 
The local federation, the "Industriearbeiter Verband," was established in 1907 in spite of the opposition of the Metal Workers' Federation, and the reluctance of some of the stronger of the sectional Unions to abandon their independence, which sentiment had proved fatal to all similar schemes in the past. It is really the offspring of the Central Committee, and is an amalgamation of about thirty-five sectional unions or groups of workers which must each be affiliated to the Central Committee. Most of these sections had previously their own constitutions and funds, though they varied greatly in influence and efficiency. The Federation only admits individual members when there is no group organisation for them to join. The total membership is more than 6,000 , of whom the manufacture of scissors employs 2,360 , table and other large knives 1,450 , razors 790 , pocket knives 540, and sword cutlery 410 . Each section appoints two delegates if its membership is less than 200 , and three if it exceeds that number. These delegates elect an executive of nine persons. When a dispute arises it is the duty of the executive to obtain full information as to its origin, the demands that are put forward, the number likely to be affected, the proportion of organised and of unorganised workers, the state of trade, and all other material circumstances, and report to the next meeting of the delegates; these may ratify a strike or boycott by a vote of not less than two-thirds of the number present. The contributions paid by the members are at the rate of $50 \mathrm{pfg}$. a week for those over sixteen years of age, and 20 pfg. a week for apprentices. Every master workman who employs a journeyman or apprentice is responsible for his contributions as well as his own. The benefits are as follows :-

Strike Pay.-Members over eighteen years of age draw 12s. a week, or if married 15s. a week and 1s. $6 \mathrm{~d}$. for each child under fourteen years, up to a maximum of 21s. a week. Apprentices receive $6 \mathrm{~s}$. when fourteen years old, increasing by $8 \mathrm{~s}$. for each additional year of age.

Out of Work Pay.-Subject to six months' continuous membership, members over eighteen years of age receive 10s. a week, under that age 4s. a week. Married members receive in addition 1s. a week for each child, up to a maximum benefit of $14 \mathrm{~s}$. a week. The benefit takes effect from the seventh day of unemployment, and is limited to six weeks' duration in one year.

Sick Pay.-Subject to one year's continuous membership adult members receive $6 \mathrm{~s}$. a week, commencing with the second week of sickness. This benefit is limited to twenty-six weeks' duration in any year. 
The effectiveness of the federation is shown by the mutual helpfulness of the branches to one another, the well-organised sections taking the part of the weaker, and refusing to work for an employer who evades the agreed scale. In this way the maintenance of the established price-list is secured even in the case of unorganised employers and workmen. The employers' associations also support the policy of making the price-list universal, and put pressure on the Unions to secure recognition of the lists by those employers who are outside the associations, these being for the most part small masters and merchants who are trying to undersell the large houses by paying low wages. In 1906 the Flat-tanged-knife Cutlers, one of the worst situated branches, secured the consent of the Table Knife Manufacturers' Association to an increased scale of prices to take effect on January 1st, 1907. The assistance of the Table Knife Grinders' Union was invoked in order to secure the adherence of the 160 employers who stood aloof from the Association. One firm, however, refused to recognise the list, and thirty outworking cutlers who had worked for the firm for decades went on strike. The inworking cutlers belonged to the Metal Workers' Federation, which refused to recognise the dispute. The inworkers, however, refused the terms offered by the firm, and both the grinders and cutlers went on strike before a settlement could be reached.

In another instance a small but well-organised branch, the Scissor Finishers, came to the assistance of the large and powerful body of Scissor Grinders. The latter had been unable to secure the recognition of a new price-list by certain of the firms standing outside the Scissor Manufacturers' Association, and in one case the dispute had lasted thirty-two years. The small but compact body of Scissor Finishers were able to bring the recalcitrant firm into line, and so terminate the long-standing quarrel in 1907.

A good example of an old exclusive craft is found in the highly skilled occupation of sword hardening, in which three families, all outworkers, enjoy a complete hereditary monopoly. All attempts to supplant them by training workers in the factories have hitherto failed.

Another interesting feature of the Solingen organisation is the prevalence of the time-honoured practice of insisting on the repayment by employers of any deficiencies of wages due to evasion of the wage scale which is proved against them. This is effected by the agency of the Conciliation Boards. During 1907 a total amount of $£ 450$ was received by the local federation from this 
source, one employer alone having to pay $£ 90$. This money is used by the Unions for the relief of necessitous workers.

Though not all the groups of workers are equally strongly organised, more than a score of craft organisations have now their own printed and ratified price-lists, and even where the organisation is most defective the federation is able to secure a fair measure of uniformity. In every branch stress is laid on the policy of discouraging the worker from becoming an employer with a handful of men working with him, though he is given every assistance in maintaining and improving his status as a bona fide workman. With this object there is one regulation which is most rigorously insisted on, namely, the one which prescribes that no master workman may employ more than one journeyman and one apprentice at the same time. This same rule, as we have already seen, was enforced by the Guild Ordinances in the sixteenth century. Thus regarded as a whole the position of the workers is exceptionally favourable, and it is not surprising to find that they present a fine body of men, remarkable alike for their prosperous industry, high intelligence, and sturdy independence.

The fact that development of factory organisation has gone on concurrently with the creation of the labour organisation above described proves that the older crafts can prosper in the new circumstances of the industry. Indeed, it may well be that the concentration that has taken place has itself been a factor favourable to efficient organisation. Though the transition to the factory system of production will run its course, it cannot be expected that the trade will for a long time to come be completely subservient to a machine process. The immense variety of products in each branch of the trade makes it very difficult to standardise patterns or to adapt automatic machinery. A single forge may, for instance, have to deal with as many as 2,000 different patterns of pocket knife blades. Again, in the grinding department the whole of the work except for some mechanical grinding of razors and table-knives is dependent on delicate manual skill, and the variability of the consistency of both steel and stone makes the problem of automatic grinding doubly baffling. Apart from these difficulties no method of machine grinding has yet been devised which can give a cutting edge to an article, and thus the finishing at least must be done by hand. So long as handwork survives the system of outwork is likely to continue. The importance of diffused electric power in this connection has been already noticed, and its influence in counteracting the tendency to concentration. A further 
condition essential to the prevalence of outwork must not be overlooked; this is the necessity of giving close attention to the improvement of technique and to the thorough training of apprentices. The former is encouraged in Solingen by the elaborately equipped " Fachschule," devoted exclusively to promoting the interests of the cutlery handicrafts, while the Industrial Code prescribes for all workers a compulsory term of apprenticeship ratified by written indentures. The period of service is determined by the rules of the individual Unions, and in most cases lasts for four years beginning with the fourteenth year of age, though in the case of razor grinding it is one year longer. It remains to be seen whether the comprehensive system of federated organisation which is now in operation will prove itself equal to the storm and stress of trade fluctuation. The Conciliation Boards are a spontaneous growth arising out of the special circumstances and needs of the industry, and thanks to the intelligence, patience, and good feeling which has prevailed on both sides have hitherto proved themselves a potent influence on the side of peace. Even the isolated cases in which they have failed to attain their object have only served to demonstrate their usefulness more completely.

The revised statutes of the Table-blade Grinders' Conciliation Board, which has been in operation since 1887, are here appended to serve as an example of the regulations which govern these bodies. A common Conciliation Board of the whole trade will shortly be established, and its rules, which are now under consideration, are expected to correspond closely to the following :-

"Statutes for the Conciliation Board between the Table-knife Manufacturers' Association and the Table-knife Grinders' Union in Solingen. Effective from March 1st, 1904.

“ 1 . The list of prices and qualities is to be mutally established by the two organisations, and similarly with every alteration thereof.

“ 2: When either organisation regards as necessary an alteration of one or of all the prices, they must send written notification of the termination of the old price-list to the other party. Three months' notice must be given, during which time the new prices must be completely arranged; they will come into force one month after the expiration of this interval, unless both parties agree upon another date. Prices for descriptions which are not included in the list, as well as for sub-divided work, come into force three months after agreement is reached.

“The Grinders' Union, after the prices have been determined, must bring evidence within an agreed interval that the majority of the employers outside the Manufacturers' Association have declared 
themselves willing to pay the same prices, and that the Union has taken the measures that are necessary to convince themselves that the obligations entered into by these employers are scrupulously carried out.

" 3. A Commission, consisting of five members appointed by each party, has been established under the name of 'Board of Conciliation' to undertake the supervision of the punctual carrying out of all the regulations concerning the price-list, and to obviate such defects as may arise.

" 4 . The members of both associations are bound to make the strict maintenance of the details as to prices and qualities estab. lished by agreement their first consideration. When a difference arises between an employer and his workmen, every effort must be made to effect a prompt settlement on the basis of the existing regulations. If such an understanding is not attained, the duty of trying to adjust the matter falls on the executive of the Grinders' Union. If a settlement is not arrived at even then, the matter will be placed in the hands of the Conciliation Board, whose decision is in every instance final. An appeal against the decision may be laid before the General Meeting of the association concerned.

"To secure more effective control every employer must supply his grinders with wage-books.

" 5 . The members of both associations are bound to submit their wage-books to the executive of their own association on demand.

" 6. Wage deficiencies which come to light through the control exercised by the Grinders' Union must be adjusted by the Executive of the Union with the employer concerned, in cases in which a memorandum relating to the point at issue has remained on the delivery note, and no notice has been taken of it by the employer. On the definite refusal of the employer to settle the matter, it must be immediately placed in the hands of the Conciliation Board, which must decide the question. Any member against whom complaints are made is bound to appear before the Conciliation Board, or to be represented; otherwise the matter will go by default.

“ 7. Wage deficiencies which the grinder himself reports to his Union within one month will be repaid to him after the settlement. Deficiences of longer standing are paid into the funds of the Conciliation Board.

" 8. Deficiences, the settlement of which falls upon the Conciliation Board, must be notified to them within six months, and must be settled by them within three months after the notification. The Board has, however, the right to extend the period for settlement in cases where difficulty arises.

" 9. If a grinder is proved to have worked for less than the list price, he must, on the application of the Union, be refused work by the members of the Manufacturers' Association until he has fulfilled the conditions imposed upon him by the Conciliation Board.

" If an employer be shown to have had grinding done below the 
list price, and refuses to comply with the conditions imposed upon him by the Conciliation Board, then, on the application of the Manufacturers' Association, no member of the Grinders' Union may work for him until he fulfils his obligations.

" 10. Neither association is authorised to take any steps against a member of the other association without the authority of the Conciliation Board. No publication in the Press of the names of members of the associations who are opposed to one another may take place in any circumstances.

“ 11. Members of the Manufacturers' Association are bound, on the decision of the Conciliation Board (when the Board regards it as absolutely necessary) to lay their books relating to the dispute in question before the Presidents of both the associations concerned.

"12. Should an employer apply for admission to the Manufacturers' Association, the first step must be to give notice to the Grinders' Union. If the Union does not inform the Manufacturers' Association within two weeks of any complaints against the employer in question, he may be admitted to membership.

" 13. Moneys accruing to the funds of the Conciliation Board will be devoted to the support of necessitous grinders, by resolution of the Board.

"14. The right of making alterations and additions to the above agreement is reserved."

G. I. H. LLOYD 